Revista Latinoamericana de la Papa 19 (2): 29-41

http://www.papaslatinas.org/revista.html

ISSN: 1853-4961

\title{
Pests and diseases affecting potato landraces and bred varieties grown in Peru under indigenous farming system
}

\section{W. Pérez Barrera ${ }^{1}$; M. Valverde Miraval ${ }^{2}$; M. Barreto Bravo ${ }^{3}$; J. Andrade-Piedra ${ }^{4}$; G. A. Forbes ${ }^{5}$}

\section{Received: 09/07/2015}

Accepted: 10/08/2015

Accessible on line: December 2015

\section{Summary}

The major pests and diseases were identified and quantified on thirteen potato landraces and three bred varieties cultivated in Peru. Late blight (Phytophthora infestans) was the primary biotic constraint affecting plants before flowering with an average severity of $24 \%$. No other pathogens caused severe foliar disease, but black scurf (Rhizoctonia solani) was relatively common on tubers of some genotypes with incidence ranging from 4.30 to $33.33 \%$. The viruses most generally considered important in potato seed degeneration, PVY and PLRV, were extremely rare, with 1.11 and $0.12 \%$ incidence, respectively. Other viruses considered mild, such as PVX and PVS, were more common, with incidence of 28.23 and $22.29 \%$, respectively. Potato flea beetle (Epitrix spp.), potato leaf beetle (Diabrotica spp.) and Andean potato weevil (Premnotrypes spp.) were common, with incidence of $28.14,18.75$ and $13.61 \%$, respectively. Potato landraces known as Ishkupuru, Lengua de vaca, Chaulina, Chaulina Tajacaja and Negro cayash were identified as potentially resistant to $P$. infestans.

Additional key words: Potato landraces, indigenous farming system, pests, resistance.

\section{Resumen}

Las principales plagas y enfermedades de papa en el Perú fueron identificadas y cuantificadas en trece variedades nativas y tres variedades mejoradas. El tizón tardío (Phytophthora infestans) fue la principal limitación biótica que afecta a las plantas antes de la floración con una intensidad promedio de $24 \%$. No hay otros patógenos que causan severos daños foliares, pero la costra negra (Rhizoctonia solani) fue relativamente común en los tubérculos de algunos genotipos de papa con incidencias que oscilan entre $4.30 \%$ y 33.33\%. Los virus generalmente considerados como los más importantes en la degeneración de semilla de papa, PVY y PLRV, fueron extremadamente raros, con una incidencia 1.11 y $0.12 \%$, respectivamente. Otros virus considerados leves, como PVX y PVS, fueron más frecuentes, con una incidencia de 28.23 y $22.29 \%$, respectivamente. La pulguilla de la papa (Epitrix spp.), el escarabajo de la hoja (Diabrotica spp.) y el gorgojo de los Andes (Premnotrypes spp.) fueron frecuentes, con una incidencia de 28.14, 18.75 y $13.61 \%$, respectivamente. Las variedades nativas de papa conocidas como Ishkupuru, Lengua de Vaca, Chaulina, Chaulina Tajacaja y Negro cayash fueron identificados como fuentes potenciales de resistencia a $P$. infestans.

\footnotetext{
Contact author. E-mail: w.perez@ cgiar.org

Senior Research Associate, International Potato Center, Lima, Peru.

Bachelor, National University Herminio Valdizan, Huanuco, Peru.

3 Bachelor, National University Daniel Alcides Carrion, Cerro De Pasco, Peru.

${ }^{4}$ Epidemiologist of Biotic constraints and potato specialist, International Potato Center, Lima, Peru.

${ }^{5}$ Strategic Program Leader- Agile Potato for Asia, International Potato Center, Heilongtan, China.
} 
Palabras claves adicionales: resistencia.

\section{Introduction}

A landrace is considered as an indigenous cultivated potato (Spooner et al., 2005) which has a high capacity to tolerate biotic and abiotic stress resulting in a high yield stability and an intermediate yield level in a low input agricultural system (Zeven, 1998).

Of the 3.500 potato landraces maintained by the International Potato Center (CIP) at its headquarters in Lima, Peru, almost 2.000 were collected in Peru (Huamán, 2001). Farmers in the departments of Huanuco, Junin, Pasco and Huancavelica produce the greatest number of potato landraces under an indigenous farming system called "'Chaqru" in the Quechua language, which involves planting mixed stands of native bitter landraces for freezedrying, or mixed stands of native floury landraces for fresh consumption, which often contain various species with different ploidy levels (de Haan et al., 2009; Zuñiga and Rojas, 2011). Through strategic alliances among public and private institutions in the Andean region, potato landraces have been reassessed in the last decade as a cultural heritage. Furthermore, technical assistance in development projects have enabled farmers in Peru to increase yields from 12 to close to $14 \mathrm{t} \mathrm{ha}^{-}$ 1 (Ordinola, 2010). Despite these efforts, pests (arthropods) and pathogens, such as the Andean weevil (Premmnotrypes spp.) and Phytophthora infestans, the cause of late blight, appear to be increasing their damage in potato landraces (Hofmaster, 1979; Pellegrini, 2013; Zuñiga and Rojas, 2011). Other pathogens (mainly viruses) affect tuber health status causing "seed degeneration" (Bertschinger et al., 1990; Jeffries, 1998; Tsror et al., 1999;
Fankhauser, 2000), but these viruses are generally not taken into account by farmers during cultivation, nor when selecting seed (Urrea, 2011). In the Andean countries, farmers generally select and store seed from one season to the next. Rarely, they may have a special seed plot, but more commonly they separate part of their harvest for seed (Thiele, 1999). There is evidence that producing seed at higher altitudes can reduce the level of viral infection (Thiele, 1999), but with climate change the incidence of virus vectors will increase at higher altitudes, which may diminish beneficial effects of high-altitude production on seed quality (Giraldo et al., 2010; Salazar, 1995). Integrated Pest Management (IPM) technologies have been developed to control different pests and diseases; however these technologies have not been widely adopted by Andean farmers for many reasons, including too few extension personnel, limited geographic coverage of extension systems, insufficient training materials and poor transportation infrastructure (Ortiz et al., 1999). Future efforts to design new extension interventions should be based on a quantification of the pest and disease problems facing Andean farmers at present. However, little is known of the incidence and severity of pests and diseases in this region, particularly in traditional landraces. The objective of the present work was to identify and catalogue the main pests and diseases affecting potato grown under ancestral planting systems in Peru and estimate the severity of the damage caused by these organisms, the following objective was to characterize the phenotypic expression of resistance to $P$. infestans in potato landraces obtained from subsistence farmers' collections. 


\section{Materials and Methods}

\section{Farmers' fields}

Sampling was done in nine fields belonging to subsistence farmers located between 3,718 and $4,090 \mathrm{~m}$ above sea level, in the district of Yanacancha (between $10^{\circ} 37^{\prime}$ to $10^{\circ} 39^{\circ} \mathrm{SL}$ ), which is in the department of Pasco (Table 1). The surface areas of the selected plots ranged between 193.20 and $1,482 \mathrm{~m}^{2}$. These farms in the central highlands of Peru were selected because they utilize the Chaqru indigenous farming system (de Haan,
2009). In this indigenous farming system, potato is planted after several years of sectorial rotation and fallow. The agroecosystem in this region is known locally as "Suni", and is characterized by cool conditions, where the average daily maximum temperature is about $15{ }^{\circ} \mathrm{C}$, and rainy weather during the potato growing season from October to April (PulgarVidal, 1996). Observations on incidence and severity pests and pathogens were made between November 2009 and May 2010.

Table 1. Characteristics of plots in the Peruvian highlands were potato plants were assessed for incidence and severity of pests and diseases.

\begin{tabular}{lccccc}
\hline \multicolumn{1}{c}{ Place } & Plot & $\begin{array}{c}\text { Altitude } \\
\text { (masl) }\end{array}$ & South Latitude & $\begin{array}{c}\text { West } \\
\text { Longitude }\end{array}$ & $\begin{array}{c}\text { Total area } \\
\text { by plot } \\
\left(\mathrm{m}^{2}\right)\end{array}$ \\
\hline Quinua & 1 & 3,894 & $10^{\circ} 37^{\prime} 19.90^{\prime \prime}$ & $76^{\circ} 10^{\prime} 25.18^{\prime \prime}$ & 880.00 \\
Quinua & 2 & 3,900 & $10^{\circ} 37^{\prime} 20.46^{\prime \prime}$ & $7610^{\prime} 25.22^{\prime \prime}$ & 783.80 \\
Quinua & 3 & 3,718 & $10^{\circ} 37^{\prime} 21.22^{\prime \prime}$ & $76^{\circ} 10^{\prime} 25.78^{\prime \prime}$ & 1747.30 \\
Quinua & 4 & 3,793 & $10^{\circ} 37^{\prime} 16.07^{\prime \prime}$ & $76^{\circ} 10^{\prime} 25.81^{\prime \prime}$ & 193.20 \\
Quichas & 5 & 4,007 & $10^{\circ} 38^{\prime} 10.66^{\prime \prime}$ & $76^{\circ} 10^{\prime} 21.78^{\prime \prime}$ & 663.40 \\
Quichas & 6 & 4,002 & $10^{\circ} 39^{\prime} 11.86^{\prime \prime}$ & $76^{\circ} 10^{\prime} 22.72^{\prime \prime}$ & 440.60 \\
Quichas & 7 & 3,972 & $10^{\circ} 37^{\prime} 10.68^{\prime \prime}$ & $76^{\circ} 10^{\prime} 21.40^{\prime \prime}$ & 408.00 \\
Quichas & 8 & 3,975 & $10^{\circ} 37^{\prime} 10.63^{\prime \prime}$ & $76^{\circ} 10^{\prime} 21.14^{\prime \prime}$ & 1482.30 \\
Candelaria & 9 & 4,090 & $10^{\circ} 36^{\prime} 76.60^{\prime \prime}$ & $76^{\circ} 10^{\prime} 24.56^{\prime \prime}$ & 1172.00 \\
\hline
\end{tabular}

${ }^{a}$ All fields were located in the district of Yanacancha, in the department of Pasco. Each plot was managed by a farmer using local production practices.

\section{Landraces and bred varieties}

Farmers had previously identified the potato landraces and bred varieties planted in mixture in each plot. Hereafter we also use the term genotype to refer to either a potato landrace or bred variety. In the Chaqru farming system seed tubers are maintained by the farmers from season to season and the potato landraces identified in the plots had from 8 to 25 years of selfsupply seed production, while the bred varieties had 7- 8 years of self-supply (Table 2). 
Table 2. Names of potato landraces and bred varieties assessed on farmers' fields in the Peruvian highlands for incidence and severity of pests and diseases and of those used in an on-farm evaluation of host plant resistance against the potato late blight pathogen, Phytophthora infestans.

\begin{tabular}{lcc|lcc}
\hline \multicolumn{2}{c|}{$\begin{array}{l}\text { Incidence and severity of pests and } \\
\text { diseases }\end{array}$} & \multicolumn{3}{c}{ Screening for resistance to P. infestans } \\
\hline Variety & Type $^{\mathbf{a}}$ & Seed age $^{\mathbf{b}}$ & Variety & Type $^{\mathbf{a}}$ & Scale value $^{\mathbf{c}}$ \\
\hline Alianza & $\mathrm{L}$ & $10-15$ & Milagro & $\mathrm{L}$ & $15.85 \mathrm{a}$ \\
Ambar & $\mathrm{L}$ & $12-15$ & Niño runtush & $\mathrm{L}$ & $14.93 \mathrm{~b}$ \\
Blanca & $\mathrm{L}$ & $8-12$ & Rurun shasha & $\mathrm{L}$ & $12.99 \mathrm{~b}$ \\
Chata negra & $\mathrm{L}$ & $15-20$ & Cunchucano & $\mathrm{L}$ & $11.96 \mathrm{c}$ \\
Wayro rojo & $\mathrm{L}$ & $12-18$ & Peruanita & $\mathrm{B}$ & $10.07 \mathrm{c}$ \\
Wayrush & $\mathrm{L}$ & $12-16$ & Wayro & $\mathrm{L}$ & $7.25 \mathrm{~d}$ \\
Ishkupuru & $\mathrm{L}$ & $15-18$ & Puca chollo & $\mathrm{L}$ & $6.57 \mathrm{~d}$ \\
Lengua de vaca & $\mathrm{L}$ & $15-20$ & Canchan & $\mathrm{B}$ & $9.00 \mathrm{~d}$ \\
Liberteña & $\mathrm{B}$ & $7-8$ & Puca wayro & $\mathrm{L}$ & $6.44 \mathrm{~d}$ \\
Muru Wayro & $\mathrm{L}$ & $15-18$ & Amarilla tumbay & $\mathrm{B}$ & $6.36 \mathrm{~d}$ \\
Negra & $\mathrm{L}$ & $18-25$ & Yana wayro & $\mathrm{L}$ & $6.32 \mathrm{~d}$ \\
Peruanita & $\mathrm{B}$ & $12-15$ & Negro cayash & $\mathrm{L}$ & $4.74 \mathrm{e}$ \\
Putish & $\mathrm{L}$ & $15-20$ & Chaulina tajacaja & $\mathrm{L}$ & $3.64 \mathrm{e}$ \\
Juito & $\mathrm{L}$ & $10-15$ & Chaulina & $\mathrm{L}$ & $3.23 \mathrm{~d}$ \\
Juito Amarillo & $\mathrm{L}$ & $9-10$ & Serranita & $\mathrm{B}$ & $1.94 \mathrm{f}$ \\
Yungay & $\mathrm{B}$ & $7-8$ & Venturana & $\mathrm{B}$ & $0.77 \mathrm{f}$ \\
\hline
\end{tabular}

${ }^{\mathrm{a}} \mathrm{L}=$ Potato landrace or $\mathrm{B}=$ bred variety

${ }^{\mathrm{b}}$ Years of on-farm seed multiplication - origin of seed prior to this is unknown

${ }^{c}$ Scale value calculated according to Yuen and Forbes (2009); in this scale, 9 is considered highly susceptible. Scale values followed by different letters are significantly different (Duncan's 5\%).

Origins of seed stocks acquired by these farmers were not known but in the case of bred varieties may have come from the national certified seed system. In the case of landraces, seed had probably been acquired locally within the informal seed system (Thiele, 1999).

\section{Foliage Evaluation}

A total of 736 plants were selected at random among all genotypes in all selected plots. The number of selected plants per plot varied according to the area of each plot (between 30 and 100). The selected plants were grouped according their morphologic characteristics. Incidence and severity of disease and pest damage were evaluated only one time on each plant just before flowering. Multiple evaluations were not made due mainly to the difficulty in accessing to the field plots and the associated costs. The period just prior to flowering was considered optimal of a single point evaluation to allow pest and pathogen buildup while avoiding confounding effects of plant aging.

Incidence was measured as the percentage of all sampled plants affected with a particular disease or pest damage in relation to the total number of plants sampled of the same genotype. Severity was estimated as the proportion of tissue per plant affected by a particular disease or pest and was averaged over all plants of the same genotype affected by specific disease or pest. To confirm the identity of certain causal agents (especially fungi), leaf samples were collected and placed in moist chambers to stimulate sporulation and facilitate diagnosis. Infected tissue 
areas bordering on healthy tissue were cultivated in Potato - Dextrose - Agar (PDA) and Vegetable V-8 Agar (V-8) emended with antibiotics when microscopic evidence was absent. The identification of fungal pathogens was based on standard taxonomic keys.

To confirm pest identification, different insect life stages (egg, larvae, pupae, or adult) were monitored on the plants, soil or debris, and then were related to damage caused on leaves according to reports in specialized potato guides (Wale et al., 2008; Hooker, 1981).

\section{Tuber Evaluation}

Tubers were harvested individually from plants evaluated for foliage symptoms and taken to the International Potato Center (CIP) laboratories in Lima, Peru for the evaluation. The tubers were washed with running water and dried with paper towels, after which they were evaluated for incidence and severity of specific potato diseases or damage caused by pests. To confirm pathogen identity, infected tissue areas bordering on healthy tissue were isolated using Potato - Dextrose - Agar (PDA) or Kelman (K) culture media and Crystal Violet Pectate Medium (CVP) for fungi and bacteria, respectively in order, especially. The identification of pathogens was based on standard taxonomic keys. To confirm pest identification, larvae were monitored on the tubers, and then were related to damage caused on tubers according to reports in specialized potato guides. Incidence was measured as the percentage of all tubers affected with a particular disease or pest damage in relation to total tubers of the same genotype. Severity was estimated as the proportion of tissue (surface or internal tissue) per tuber affected by a particular disease or pest and averaged among all tubers of the same genotype affected by specific disease or pest.

\section{Diagnosis of viruses}

One tuber from each selected plant was chosen at random among all tubers harvested and subjected to temperature fluctuations ( 8 to $20{ }^{\circ} \mathrm{C}$ every two weeks during two at three months) to induce sprouting. The apical bud from each tuber was then extracted aseptically and placed individually in rooting trays. Once rooted, the shoots were transplanted in pots of 7.6 $\mathrm{cm}$ diameter filled with the artificial substrate Pro-mix BX (Premier peat moss, Rivière-du-Loup, Quebec, Canada). Transplants were maintained in a vectorfree screen house until the plants were 15 $\mathrm{cm}$ high. Leaves of the apical part of each plant were aseptically removed and processed for DAS-ELISA diagnosis of potato virus $\mathrm{X}(\mathrm{PVX})$, potato virus $\mathrm{Y}$ (PVY), potato leafroll virus (PLRV), potato virus $S$ (PVS), Andean potato latent virus (APLV), Andean potato mottle virus (APMoV) and potato "mop-top" virus (PMTV), using CIP's Operational procedure No. 19 based on the FAO/IPGRI Technical Guidelines for the Safe Movement of Germplasm No. 19 - Potato (Jeffries, 1998). Incidence of each virus was measured as the percentage of plants with positive reaction in DAS-ELISA in relation to the total number of plants of the same genotype tested. Evaluations of viral infection were made between May and October 2010.

\section{Screening for Late Blight in subsistence farmers' collection}

Germplasm used in this study was obtained from farmers' collections from the districts Paucartambo (between $10^{\circ} 45^{\prime}$ to $10^{\circ} 48^{\prime}$ ' south latitude) and Yanacancha (between $10^{\circ} 37^{\prime}$ to $10^{\circ} 39^{\prime} \mathrm{S}$ in the department of Pasco, and the district of Ulcumayo ( $10^{\circ}$ $58^{\prime}$ to $10^{\circ} 65^{\prime} \mathrm{SL}$ ), which is in the department of Junin. An on-farm field trial was carried out between October 2013 and April 2014. The experiment was installed in a farmer's plot (3623 masl, 1044'10.72" SL) near Paucartambo, This is a location of consistently high disease pressure and 
where all farming activities are based on the Chaqro farming system.

Thirteen local potato landraces (Table 2) used widely in the indigenous farming system were evaluated for resistance to $P$. infestans, the cause of potato late blight. Three Peruvian genotypes (Venturana, Serranita, and Canchan) with different levels of resistance were used as controls. Planting density was $0.9 \mathrm{~m}$ between rows and $0.35 \mathrm{~m}$ between plants. The plants were protected against $P$. infestans with a contact fungicide (Mancozeb 45\%) for the first 35 days after planting, after which they were exposed to natural infection with no further fungicide applications. The experiment was carried out in a randomized complete block design with three replications (Box et al., 1999). The percentage of leaf area affected of each plant was evaluated weekly after 42 days of planting. A total of fourteen disease severity readings were recorded. The relative area under the disease progress curve (rAUDPC) was calculated for each genotype from ratings of foliar infection. The rAUDPC values were then used to calculate susceptibility scale values for each genotype (Yuen and Forbes, 2009) and for this purpose a scale value (SV) of 9 was assigned to Canchan, known for its high susceptibility to late blight. Analysis of variance and means comparisons procedures (Duncan's) were used to compare SV values using SAS 9.2 statistical software (SAS Institute Inc., Cary, NC).

\section{Results}

\section{Diseases and pests affecting foliage}

Late blight was the only disease or pest causing significant damage to foliage (Table 3). On average, late blight was present in $84 \%$ of plants (range $50-100$ $\%$ ) and caused an average foliar damage of $24 \%$ (range $4-40 \%$ ). Early blight incidence was on average $7 \%$ and caused little or no damage to foliage. Incidence of plants with insect damage ranged from 14 to $28 \%$ however damage to foliage was only between 1 and 3\%. Given the low damage of most diseases and pests, varietal differences were only considered for late blight. Ishkupuru and Lengua de vaca had very low levels of late blight severity in this survey. 
Table 3. Incidence and severity of the most important diseases and pests found on potato landraces and bred varieties in the Peruvian highlands.

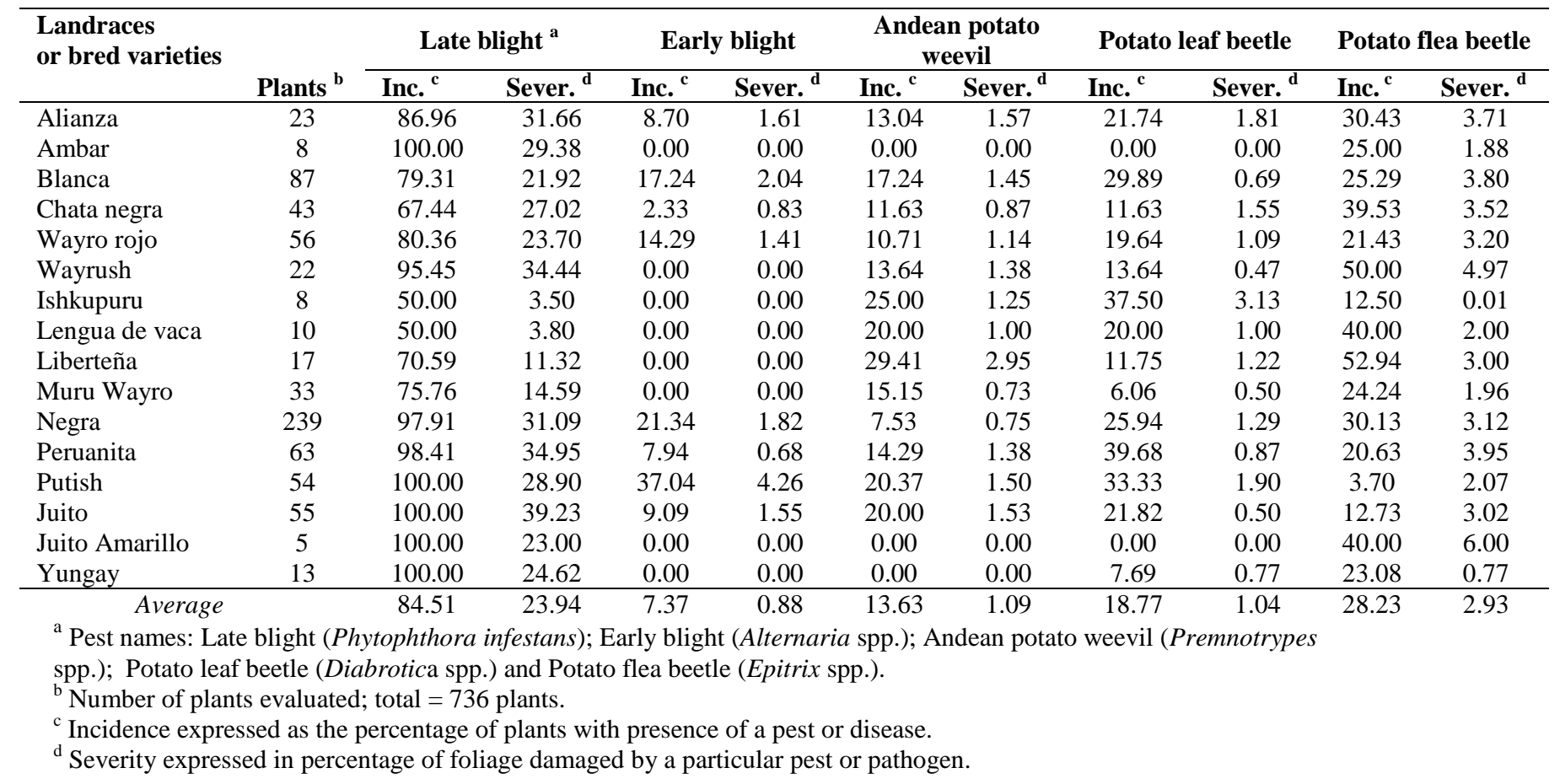

Systemic virus infection and tuber borne pests

The viruses $\mathrm{X}$ and $\mathrm{S}$ were found in 28.39 $\%$ and $22.13 \%$ of the plants, respectively, and thus were the most common of viruses tested. The remaining viruses were relatively rare with APMoV, APLV, PVY, PLRV and PMTV being found in $3.82 \%$, $2.11 \%, 1.16 \%, 0.35 \%$ and $0.15 \%$ of plants, respectively (Table 4).

Table 4. Incidence of seven viruses found in potato landraces and bred varieties in the Peruvian highlands.

\begin{tabular}{lccccccccc}
\hline & & \multicolumn{9}{c}{ Incidence $^{\mathbf{a}}$} \\
\cline { 2 - 9 } Variety & Plants $^{\mathbf{b}}$ & PVX & PVY & PLRV & PVS & APLV & APMoV & PMTV \\
\hline Alianza & 23 & 8.70 & 0.00 & 4.35 & 17.39 & 0.00 & 26.09 & 0.00 \\
Ambar & 8 & 0.00 & 0.00 & 0.00 & 12.50 & 0.00 & 12.50 & 0.00 \\
Blanca & 87 & 36.78 & 0.00 & 0.00 & 18.39 & 1.15 & 0.00 & 0.00 \\
Chata negra & 43 & 16.28 & 2.33 & 0.00 & 39.53 & 2.33 & 0.00 & 2.32 \\
Wayro rojo & 56 & 23.21 & 0.00 & 0.00 & 23.21 & 0.00 & 1.79 & 0.00 \\
Wayrush & 22 & 18.18 & 0.00 & 0.00 & 31.82 & 0.00 & 13.64 & 0.00 \\
Ishkupuru & 8 & 50.00 & 0.00 & 0.00 & 25.00 & 0.00 & 0.00 & 0.00 \\
Lengua de vaca & 10 & 70.00 & 10.00 & 0.00 & 40.00 & 10.00 & 0.00 & 0.00 \\
Liberteña & 17 & 29.41 & 5.88 & 0.00 & 35.29 & 5.88 & 5.88 & 0.00 \\
Muru Wayro & 33 & 21.21 & 0.00 & 0.00 & 15.15 & 0.00 & 0.00 & 0.00 \\
Negra & 239 & 14.23 & 0.42 & 1.26 & 33.89 & 0.42 & 1.26 & 0.00 \\
Peruanita & 63 & 17.46 & 0.00 & 0.00 & 17.46 & 4.76 & 0.00 & 0.00 \\
Putish & 54 & 40.74 & 0.00 & 0.00 & 24.07 & 3.70 & 0.00 & 0.00 \\
Juito & 55 & 21.82 & 0.00 & 0.00 & 12.73 & 5.45 & 0.00 & 0.00 \\
Juito amarillo & 5 & 40.00 & 0.00 & 0.00 & 0.00 & 0.00 & 0.00 & 0.00 \\
Yungay & 13 & 46.15 & 0.00 & 0.00 & 7.69 & 0.00 & 0.00 & 0.00 \\
& & 28.39 & 1.16 & 0.35 & 22.13 & 2.11 & 3.82 & 0.15 \\
\hline
\end{tabular}

${ }^{a}$ Incidence of seven viruses tested using ELISA, expressed as percentage of plants with presence of each virus percentage (\%).

bumber of evaluated plants; total $=736$ plants

${ }^{c}$ Virus acronyms : PVX=Potato virus X; PVY = Potato virus Y; PLRV = Potato leafroll virus; APLV = Andean potato latent virus; APMoV

$=$ Andean potato mottle virus; PMTV $=$ potato mop - top virus. 


\section{ARTÍCULO DE INVESTIGACIÓN}

Revista Latinoamericana de la Papa 19 (2): 29-41

ISSN: 1853-4961

http://www.papaslatinas.org/revista.html

It is important to note that PVY and PLRV, considered the most important potato viruses worldwide, were found at a very low frequency.

The most frequently found tuber disease was black scurf caused by Rhizoctonia solani with an average incidence of 14.27 $\%$ and severity ranging from 1.07 to $15.00 \%$ (Table 5). The second most important problem on tubers was caused by the Andean weevil larvae (Premnotrypes spp), with $8.27 \%$ average incidence and severity ranging from 1.31

to $15.03 \%$. Powdery scab (Spongospora subterranea), dry rot (Fusarium spp.), tuber blight ( $P$. infestans), and soft rot (Pectobacterium spp.) had average incidences of $3.47 \%, 2.92 \%, 1.47 \%$ and $1.11 \%$, respectively. Anthracnose caused by Colletotrichum spp. had an average incidence of $7.65 \%$. Genotypes appeared to differ in susceptibility to Colletotrichum spp., as Alianza, Ambar and Putish had incidences between 20 and 30\%, while the other genotypes had no symptoms (Table $5)$.

Table 5. Incidence and severity of the most important potato diseases and pests found in tubers of potato landraces and bred varieties surveyed in the Peruvian highlands.

\begin{tabular}{|c|c|c|c|c|c|c|c|c|c|c|c|c|c|c|c|}
\hline \multirow[b]{2}{*}{ Variety } & \multirow[b]{2}{*}{$\underset{\mathbf{b}}{\text { Tubers }}$} & \multicolumn{2}{|c|}{ Black scurf $^{\text {a }}$} & \multicolumn{2}{|c|}{ Dry rot } & \multicolumn{2}{|c|}{ Powdery scab } & \multicolumn{2}{|c|}{ Soft rot } & \multicolumn{2}{|c|}{ Late blight } & \multicolumn{2}{|c|}{ Black dot } & \multicolumn{2}{|c|}{$\begin{array}{c}\text { Andean potato } \\
\text { weevil }\end{array}$} \\
\hline & & Inc. $^{c}$ & Sever. $^{d}$ & Inc. & Sever. & Inc. & Sever. & Inc. & $\begin{array}{c}\text { Sever } \\
.\end{array}$ & Inc. & $\begin{array}{c}\text { Sever } \\
.\end{array}$ & Inc. & $\begin{array}{l}\text { Sev } \\
\text { er. }\end{array}$ & Inc. & Sever. \\
\hline Alianza & 232 & 8.62 & 1.34 & 1.72 & 1.30 & 1.29 & 0.13 & 0.43 & 0.63 & 0.00 & 0.00 & 29.74 & 4.02 & 11.64 & 8.89 \\
\hline Ambar & 72 & 33.33 & 3.75 & 1.39 & 1.25 & 0.00 & 0.00 & 0.00 & 0.00 & 0.00 & 0.00 & 27.78 & 6.25 & 6.94 & 4.38 \\
\hline Blanca & 1263 & 14.01 & 2.56 & 2.53 & 2.10 & 2.06 & 1.88 & 0.87 & 1.33 & 2.69 & 1.54 & 0.71 & 0.20 & 14.33 & 6.79 \\
\hline Chata negra & 406 & 4.19 & 1.07 & 3.20 & 1.94 & 2.46 & 1.35 & 3.20 & 0.96 & 3.45 & 1.83 & 8.13 & 1.90 & 6.65 & 15.19 \\
\hline Wayro rojo & 384 & 6.25 & 2.16 & 6.25 & 2.14 & 2.60 & 1.56 & 1.56 & 0.56 & 2.34 & 0.95 & 3.65 & 1.08 & 14.58 & 10.17 \\
\hline Wayrush & 206 & 10.68 & 2.50 & 2.43 & 3.07 & 1.94 & 2.50 & 0.00 & 0.00 & 0.49 & 1.25 & 0.00 & 0.00 & 14.08 & 16.00 \\
\hline Ishkupuru & 69 & 20.29 & 4.38 & 1.45 & 1.25 & 5.80 & 1.25 & 4.35 & 2.50 & 0.00 & 0.00 & 0.00 & 0.00 & 1.45 & 0.63 \\
\hline Lengua de vaca & 117 & 9.40 & 15.00 & 0.85 & 10.00 & 13.68 & 15.00 & 3.42 & 10.00 & 5.13 & 10.00 & 0.00 & 0.00 & 1.71 & 5.00 \\
\hline Liberteña & 318 & 5.35 & 2.50 & 5.97 & 3.86 & 7.23 & 2.29 & 2.52 & 1.74 & 5.97 & 3.20 & 0.00 & 0.00 & 1.26 & 0.69 \\
\hline Muru Wayro & 358 & 10.06 & 2.15 & 0.84 & 0.64 & 5.59 & 2.77 & 0.56 & 0.75 & 3.35 & 1.88 & 12.01 & 2.75 & 8.66 & 13.15 \\
\hline Negra & 1867 & 18.37 & 3.85 & 1.34 & 1.30 & 4.02 & 1.86 & 0.54 & 0.29 & 0.05 & 0.07 & 14.89 & 2.65 & 7.61 & 6.83 \\
\hline Peruanita & 916 & 24.24 & 4.62 & 0.44 & 0.69 & 0.98 & 0.95 & 0.11 & 0.26 & 0.00 & 0.00 & 3.17 & 0.68 & 15.07 & 8.71 \\
\hline Putish & 512 & 10.55 & 1.84 & 2.73 & 1.72 & 1.56 & 1.10 & 0.20 & 0.18 & 0.00 & 0.00 & 22.07 & 3.34 & 5.86 & 3.67 \\
\hline Juito & 488 & 22.95 & 4.07 & 1.02 & 0.79 & 3.28 & 1.64 & 0.00 & 0.00 & 0.00 & 0.00 & 0.20 & 0.21 & 14.55 & 5.45 \\
\hline Juito amarillo & 49 & 16.33 & 6.00 & 6.12 & 4.00 & 0.00 & 0.00 & 0.00 & 0.00 & 0.00 & 0.00 & 0.00 & 0.00 & 4.08 & 10.00 \\
\hline Yungay & 131 & 13.74 & 1.54 & 8.40 & 4.62 & 3.05 & 1.69 & 0.00 & 0.00 & 0.00 & 0.00 & 0.00 & 0.00 & 3.82 & 1.92 \\
\hline Average & & 14.27 & 3.71 & 2.92 & 2.54 & 3.47 & 2.25 & 1.11 & 1.20 & 1.47 & 1.30 & 7.65 & 1.44 & 8.27 & 7.34 \\
\hline
\end{tabular}

${ }^{a}$ Pest names: Black scurf (Rhizoctonia solani); Dry rot (Fusarium spp.); Powdery scab (Spongospora subterranea); Soft rot

(Pectobacterium spp.); late blight (Phytophthora infestans); Black dot (Colletotrichum spp.); Andean potato weevil

(Premnotrypes spp.).

${ }^{\mathrm{b}}$ Number of tubers evaluated; total $=7,388$ tubers.

${ }^{\mathrm{c}}$ Incidence expressed as the percentage of plants with presence of a particular pest or disease.

${ }^{\mathrm{d}}$ Severity expressed as the percentage of tuber area damaged by a particular pest or pathogen.

\section{Screening for Late Blight in subsistence farmers' collection}

Susceptibility scale values calculated for five genotypes (Milagro, Niño runtush, Rurun sasha, Cunchucano and Peruanita) were higher (between 15.85 and 10.07) than those obtained for Canchan $(\mathrm{SV}=$ 9.00), used as a susceptible control in the experiment (Table 2). Venturana (SV= 0.77) and Serranita (SV=1.94) had the lowest susceptibility scores but several landraces also had relatively low scores: Chaulina (SV=3.23), Chaulina Tajacaja
$(\mathrm{SV}=3.64)$ and Negro cayash $(\mathrm{SV}=4.74)$. The other seven genotypes obtained values between 6.32 to 7.25 , indicating an intermediate level of infection.

\section{Discussion}

In this study, late blight, caused by the oomycete $P$. infestans, was the main biotic constraint in potato landraces cultivated in Pasco, Peru. This disease was also recently reported as the most important in fields located between 3400 to $3900 \mathrm{~m}$ of altitude in the departments of Huancavelica, Huánuco, Pasco and Junín (Zuñiga and 
Rojas, 2011). P. infestans has also been isolated in the last few years from potato landraces growing at 4225 masl in the central highlands of Peru, which is significantly higher than any isolations previously recorded in the International Potato Center's isolate database (unpublished data). These results are consistent with GIS based analyses of future climate scenarios that suggest an increase in late blight severity at higher altitudes (Giraldo et al., 2010).

The low severity of early blight found in landraces and bred varieties may be due to weather conditions, as early blight is favored by warmer temperatures (Agrios, 2005). However, low early blight severity may also reflect host resistance in the Andean landraces, which has been reported previously (Torres and Ames, 1995).

Similar to our results, de Haan et al. ( 2009) also found black scurf to be the most important tuber borne problem of potato landraces in Peru. Incidence of black scurf was also found to be very high in farmer's seed tubers $(78 \%)$ in Ecuador (Fankhauser, 2000). Anthracnose (Colletotrichum spp.) was found at relatively high frequency in some genotypes, but this disease is rarely cited as a problem in the high Andes. We assume that this disease is poorly identified by many farmers because the tuber skin color dissimulates the spots caused by this pathogen.

Hofmaster (1979) mentioned that severe foliage damage caused by Epitrix spp. is not always associated with severe damage in the tuber, so that plants with light leaf damage may suffer severe damage to the tuber, and vice versa. This may explain why we found low damage of tubers caused by Epitrix spp. in spite of relatively high incidence in foliage.

Alcazar and Cisneros (1999) reported that the complex of Premnotrypes spp. causes severe damage to potato crops from Argentina to Venezuela at altitudes above
$2800 \mathrm{~m}$. Damage from Andean weevil ( $P$. vorax) was also found to be high in farmer's seed of bred varieties in Ecuador (Fankhauser, 2000). Alcazar and Cisneros (1991) found significant differences between species of Solanum in relation to the damage caused by the adult Andean potato weevil in the foliage and of larvae in the tubers. Thus, the highly variable results we found among landraces could reflect either patchiness in the presence of the pest, host resistance or some combination of these factors.

Consistent with our results, another study carried out in Peruvian central highlands (Scurrah et al., 2009), found that the main viruses affecting potato landraces were PVX, PVS, APMV and APLV, whereas PVY and PLRV were found in very low frequencies. de Haan (2009) also reported low incidence of infection with PMTV, PLRV and PVY, however APMoV and PVX were found to have relatively high overall infection incidences of $18.1 \%$ and $47 \%$, respectively. That report was based on serological tests done on 1317 samples of potato landraces from different Peruvian highland communities.

Contrary results were reported by Bertschinger (1992) who found that the incidence of PLRV and PVY was significantly higher than PVX and PVS in potato landraces than in bred cultivars (Bertschinger et al., 1990). In the latter case, the potato landraces may have been planted at elevations below $3000 \mathrm{~m}$ where vector populations were higher.

Global warming has facilitated the development and dissemination of some insects such as whiteflies (Morales et al., 2006) and Phthorimaea operculella (Kroschel et al., 2013). Similarly, climate change in highland areas such as the Andes will lead to increased activity of aphid virus vectors. Consistent with this trend, one study carried out above 4000 masl, demonstrated that the aphids Myzus persicae Sulz. and Lipaphis erysimi 
(Kaltenbach) were transmitting APLV from Maca ( Lepidium peruvianum ) to potato with an incidence of 1 to $3 \%$ (Chuquillanqui et al. 2004).

In our study, the potato landraces known as Ishkupuru, Lengua de vaca, Chaulina, Chaulina Tajacaja and Negro cayash had very low LB severity and may be potential sources of resistance to that disease either directly as landrace varieties or as parents in crosses. Consistent with our results, (Perez et al., 2014) found that nineteen accessions of potato landraces from the CIP germplasm collection had LB resistance levels better than or similar to the resistant variety used as a control. Other studies have reported high levels of resistance to late blight in potato landraces in Peru (Gastelo et al., 2010), Bolivia (Plata et al., 2000), and Ecuador (Cañizares and Forbes, 1995).

The vary low incidence of plants containing the major yield-reducing viruses that we found and reported elsewhere (Scurrah et al., 2009) would indicate that simple positive selection may maintain seed health levels indefinitely in these highland landraces, although as noted above, increasing temperatures may increase disease pressure. Nonetheless, studies have shown that most farmers do not take tuber health into consideration when selecting tubers for the next cropping season (Gamboa, 1993). Furthermore, it would appear that virus infection is often not recognized by farmers and in an extreme case, some Andean farmers believe that plants showing yellowing symptoms, like that caused by potato yellow vein virus (PYVV), foretell a good harvest (Salazar, 1995). These observations highlight the alreadyrecognized need to include capacity to identify virus symptoms in the training for positive selection (Gildemacher et al., 2011).

\section{Conclusion}

Due to climate change, and particularly global warming phenomenon, some highaltitude Andean communities have recently reported losses caused by diseases and pests, such as late blight and Andean Potato Weevil, which were generally considered minor problems in the past. Our study confirmed these facts are consistent with this change, but at the same time we have identified potato landraces with resistance to late blight under these conditions. Thus, one recommendation would seem to be researchers continue evaluating native landraces for late blight resistance, but in the immediate future, extension workers could use our results to recommend landraces for those areas where the disease is most severe.

Although the most yield-limiting viruses were not found in high frequency in our study, this could easily change with increasing temperatures. The majority of potato landraces only can be propagated with seed from own farmers' plots, however, is possible to reduce viral infection and increase the yields using simple techniques as positive or negative selection, for which farmers must be instructed. All these activities needs to enhance farmer capacity for integrated management and promote the use of seed quality, these issues must and should be considered by ONGs non-governmental and governmental organizations and national programs in their training and interventions activities.

\section{Conflicts of interest}

This research was realized in the International Potato Center and no conflicts of interest.

\section{Acknowledgements}

This work was funded by the Mc. Knight Foundation (http://www.mcknight.org/). We thank Mr. Elvin De la Torre for their technical assistance in the greenhouse and laboratory work. 


\section{References}

Agrios, G.N. 2005. Plant Pathology. Fifth Edition. Elsevier Academic Press. USA. $952 \mathrm{p}$.

Alcazar, J.; Cisneros, F. 1991. Susceptibilidad de seis especies de Solanum al Premnotrypes suturicallus Kuschel (Coleóptera: Curculionidae). Revista Peruana de Entomología 34: 1058.

1999. Taxonomy and bionomics of the Andean Potato Weevil complex: Premnotrypes spp. and related genera. CIP Program Report 1997-98. International Potato Center (CIP). Lima, Peru. pp. 141151.

Bertschinger, L. 1992. Modelling of potato virus pathosystems by means of quantitative epidemiology: an exemplary case on virus degeneration studies in Peru. Swiss Federal Institute of Technology. Thesis Ph.D. Zürich, Switzerland. 111 p.

Bertschinger, L.; Scheidegger, U.C.; Luther, K.; Pinillos, O.; Hidalgo, A. 1990. La incidencia de virus de papa en cultivares nativos y mejorados en la sierra Peruana. Revista Latinoamericana de la papa. 3 (1): 62-79.

Box, G.E.P.; Hunter, W.G.; Hunter, J.S. 1999. Estadística para investigadores: Introducción al diseño de experimentos, análisis de datos y construcción de modelos. Reverte Ediciones. México. 675 p.

Cañizares, C.A.; Forbes, G.A. 1995. Foliage resistance to Phythophthora infestans (Mont.) de Bary in the Ecuadorian national collection of Solanum phureja ssp. phureja Juz. \& Buk. Potato Research 38: 3-10.

Chuquillanqui, C.; Fuentes, S.; Salazar L. 2004. Prospección de enfermedades virales en el cultivo de Maca (Lepidium peruvianum) en la provincia de Junín. 18 Congreso Peruano de Fitopatologia. Resúmenes.Huaráz, Perú. p. 41.
De Haan, S. 2009. Potato diversity at height: multiple dimensions of farmerdriven in-situ conservation in the Andes. Wageningen Agricultural University (WAU). Thesis Ph.D. The Netherlands. $244 \mathrm{p}$.

De Haan, S.; Almekinders, C.; Thiele, G.; Ccanto, R.; Scurrah, M. 2009. Seed procurement of Native Potatoes in the Central Andes of Peru: The Role of Farmer-to-Farmer Exchange, Markets and Seed Fairs. International Society for Tropical Root Crops (ISTRC). Tropical roots and tubers in a changing climate: A critical opportunity for the world, Program and Abstracts of papers. Lima, Peru.p. 81.

Fankhauser, C. 2000. Seed-Transmited diseases as constraints for potato production in the tropical highlands of Ecuador. Swiss Federal Institute of Technology. Natural Sciences Faculty. Thesis Ph.D. Zürich, Switzerland. 125 p.

Gamboa, D. 1993. Sistemas de producción y multiplicación de semilla de papa bajo una lógica campesina. Universidad Mayor de San Simón. Tesis. Cochabamba, Bolivia.

Gastelo, M.; Arcos, J.; Landeo, J.; Bonierbale, M. 2010. Nuevas variedades de papa Solanum tuberosum spp. andigena (BIC5), obtenidas a través de la selección participativa por los agricultores de las comunidades del Altiplano, Puno - Perú. Papanat 2010. Instituto Nacional de Investigaciones Agropecuarias (INIAP). Quito - Ecuador. Memorias. pp. 19-20.

Gildemacher, P.R.; Schulte-Geldermann, E.; Borus, D.; Demo, P.; Kinyae, P.; Mundia, P.; Struik, P.C. 2011. Seed potato quality improvement through positive selection by smallholder farmers in Kenya. Potato Research. 54 (3): 253 - 266.

Giraldo, D.; Juárez, H.; Pérez, W.; Trebejo, I.; Yzarra, W.; Forbes, G. 2010. Severidad del tizón tardío de la papa (Phytopthora infestans) en zonas agrícolas del Perú 
asociado al cambio climático. Revista Peruana Geo-Atmosférica 2: 56-67.

Hofmaster, R.N. 1979. The potato flea beetle on Irish potatoes. The Vegetable Growers News 33 (11): 1 - 3.

Hooker, W.J. (ed.). 1981. Compendium of Potato Diseases. St. Paul Minnesota, USA: American Phytopahtological Society. USA. 125 p.

Huamán, Z. 2001. Semilleros Comunales de papas nativas del Perú. Biodiversidad 30: $20-22$.

Jeffries, C. J. 1998. Potato. FAO/IPGRI Technical Guidelines for the Safe Movement of Germplasm. FAO/IPGRI/SASA. Rome, Italy. 177 p.

Kroschel, J.; Sproleder, M.; Tonnang, H.E.Z.; Juárez, H.; Carhuapoma , P.; Gonzales, J.C.; Simon, R. 2013. Predicting climate - change - caused changes in global temperature on potato tuber moth Phthoriamea operculella (Zeller). Distribution and abundance using phenology modeling and GIS mapping. Agricultural and Forest Meteorology 170: $228-241$.

Morales, F.J.; Cardona C.; Bueno, J.M.; Rodríguez, I. 2006. Manejo integrado de enfermedades de plantas causadas por virus transmitidos por moscas blancas. Centro Internacional de Agricultura Tropical (CIAT). Cali, Colombia. 43 p.

Ordinola, M. 2010. Poniendo en valor las papas nativas en el Perú. Revista Latinoamericana de la Papa 15 (1): 97-99.

Ortiz, O.; Winter, P.; Fano, H.; Thiele, G.; Guaman, S.; Torres, R.; Barrera, V.; Unda, J.; Hakiza, J. 1999. Understanding farmers' responses to late blight: evidence from Peru, Bolivia, Ecuador, and Uganda. In Impact on a Changing World: Program Report, 1997- 1998. International Potato Center (CIP). Lima, Peru. pp. 101-109.

Pellegrini, F. 2013. Evaluation of integrated pest management (IPM) adoption in potato production using the sustainable livelihoods approach - a qualitative study from central Ecuador. Swedish University of Agricultural Science. Master Thesis in Agricultural Science. Alnarp, Sweden. 70 p.

Perez, W.; Nahui, M.; Ellis, D.; Forbes, G. 2014. Wide phenotypic diversity for resistance to Phytophthora infestans found in potato landraces from Peru. Plant Disease 98 (11): 1530-33.

Plata, G.; Coca, A.; Carrasco, E. 2000. Papa nativa Boliviana: potencial para nuevas fuentes de resistencia durable al tizón de la papa (Phytophthora infestans). Fundación para la Promoción e Investigación de Productos Andinos (PROINPA). Segunda reunión boliviana sobre recursos fitogenéticos de cultivos nativos. Cochabamba, Bolivia. Memorias. pp. 187-191.

Pulgar-Vidal, J. 1996. Geografía del Perú: Las ocho regiones naturales, la regionalización transversal, la sabiduría tradicional. 10th ed. PEISA. Lima, Perú. $302 \mathrm{p}$.

Salazar, L. 1995. Los virus de la papa y su control. Centro Internacional de la Papa (CIP). Lima, Perú. 226 p.

Scurrah, M.; Ccanto, R.; Olivera, E.; Bejarano, J.; de Haan, S.; Muller, G.; Salas, E.; Mihovilovich, E.; Bonierbale, M.; Barker I. 2009. Are viruses important in native seed systems in Huancavelica, Peru? viruses and Andean seed systems. International Society for Tropical Root Crops (ISTRC). Tropical roots and tubers in a changing climate: A critical opportunity for the world. Program and Abstracts of Papers. Lima, Peru. p. 82

Spooner, D.; McLean, M, K.; Ramsay, G.; Waugh, R.; Bryan, G. J. 2005. A single domestication for potato based on multilocus amplified fragment length polymorphism genotyping. Proceedings of the National Academy of Sciences of the United States of America 102 (41): 14694. 
Thiele, G. 1999. Informal potato seed systems in the Andes: why are they important and what should we do with them? World Development 27 (1): 83-99.

Torres, H.; Ames T. 1995. Tizón temprano (Alternaria solani), síntomas, especies, producción de inóculo y evaluación de resistencia. Programa Cooperativo de Investigación en papa (PROCIPA) Control integrado de las principales enfermedades fungosas de la papa. Instituto Nacional de Investigaciones Agropecuarias de Uruguay (INIA); Centro Internacional de la Papa (CIP). Lima, Perú. pp. 27-30.

Tsror, L.; Aharon, M.; Erlich, O. 1999. Survey of bacterial and fungal seedborne diseases in imported and domestic potato seed tubers. Phytoparasitica 27 (3): 21526.

Urrea, C. 2011. Understanding perceptions of potato seed quality among small-scale farmers in Peruvian highlands. Wageningen University. M. Sc. Thesis in marketing and consumer behaviour. Wageningen, The Netherlands. $52 \mathrm{p}$.

Wale, S.; Plat, H.W.; Cattlin, N. 2008. Diseases, Pests and Disorders of Potatoes: A Colour Handbook. Plant Protection Handbook Series. Manson Publishing Ltd. California, USA. 176 p.

Yuen, J.E.; Forbes, G.A. 2009. Estimating the level of susceptibility to Phytophthora infestans in potato genotypes. Phytopathology 99: 783-86.

Zeven, A.C. 1998. Landraces: a review of definitions and classifications. Euphytica 104: 127-39.

Zuñiga, N.; Rojas, J. 2011. Zonas agroecológicas de la sierra central del Perú donde se cultiva papas nativas. Instituto Nacional de Innovación Agraria (INIA).Huancayo, Perú. 88 p. 